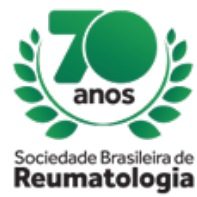

\title{
REPORT OF LUPUS PATIENT WITH BILATERAL OPTIC NEURITIS
}

Letícia Lopes Coimbra (Hospital Geral de Palmas. Universidade Federal do Tocantins., Palmas, TO, Brasil), Maria Luiza Silva Brito (Hospital Geral de Palmas. ., Palmas, TO, Brasil), Allethéa Robertha Souza e Silva (Hospital Geral de Palmas., Palmas, TO, Brasil), Maria Eduarda Guimarães Leal (Hospital Geral de Palmas. Universidade Federal do Tocantins., Palmas, TO, Brasil), Danilo Garcia Ruiz (Hospital Geral de

Palmas., Palmas, TO, Brasil), Daniela Maria Edilma Japiassú Custódio (Hospital Geral de Palmas.,

Palmas, TO, Brasil), Hugo de Carlos Maciel Rossoni (Hospital Geral de Palmas., Palmas, TO, Brasil), Paulo Geovanny Pedreira (Hospital Geral de Palmas., Palmas, TO, Brasil), Paola Bottin Madrid (Hospital Geral de Palmas., Palmas, TO, Brasil), Rafaela Alen Costa Freire (Hospital Geral de Palmas., Palmas, TO, Brasil)

\section{BACKGROUND}

: Optic nerve disease, which is symbolized by optic neuritis and ischemic optic neuropathy, affects approximately $1 \%$ of patients with Systemic Lupus Erythematosus (SLE) and has been correlated with the presence of antiphospholipid antibodies, nephropathy, and increased mortality. Autoimmune optic neuropathy results from ischemia of the optic nerve combined with demyelinating lesions. Treatment is by corticosteroid.

\section{CASE REPORT}

Patient B.L.S., female, 37 years old, from Palmas-TO, previously diagnosed with SLE, sought hospital care with complaint of progressive visual acuity reduction for 2 months. He was taking hydroxychloroquine $400 \mathrm{mg} /$ day, prednisone 30mg / day. An ophthalmologic exam was performed, which evidenced papilla edema. Performed a brain resonance, without alterations, and resonance of orbits, which evidenced bilateral optic neuritis. Pulse therapy with methylprednisolone $1 \mathrm{~g} /$ day was started for 3 days. Serologies were negative for toxoplasmosis, Epstein-Barr virus, cytomegalovirus, calazar detect, hepatitis $\mathrm{B}$, hepatitis C, VDRL and HIV. Reagent laboratory tests: anti-SM; anti-RNP; FAN 1/640 core; anti-B2 glycoprotein 1 IgM; Non-reagent laboratory tests: anti-RO; anti-LA; anti-dna; anti-csL70; lupus anti-coagulant; antimitochondria; anti-cardiolipin IgM and IgG; anti-TPO. Had proteinuria 24 hours of $1049 \mathrm{mg}$. Patient evolved with improvement of visual symptoms, receiving hospital discharge with hydroxychloroquine $400 \mathrm{mg} /$ day, prednisone $60 \mathrm{mg} /$ day, calcium carbonate $1 \mathrm{x} /$ day and omeprazole $40 \mathrm{mg} /$ day. After 5 months, she returns with total loss of vision of the right eye and blurred vision in the left eye. In the use of hydroxychloroquine $400 \mathrm{mg}$ / day, prednisone $20 \mathrm{mg}$ / day, calcium, vitamin D, omeprazole $20 \mathrm{mg} /$ day and azathioprine 50mg 8 / 8 hours. Sequelae lesions were identified bilaterally on examination, with no evidence of acute injury or reactivation of the disease. New resonance did not show alteration when compared to previous one. She presented proteinuria 24 hours oscillating, at the moment with $675 \mathrm{mg}$ and during hospitalization of $450 \mathrm{mg}$. Azathioprine was discontinued and the patient started pulse therapy with methylprednisolone $1 \mathrm{~g} /$ day for 3 days and started pulse therapy with cyclophosphamide, which was maintained at $1 \mathrm{~g} /$ month for 6 months per oscillating nephritis.

\section{CONCLUSION}

A difficult diagnosis is due to the rarity of this neuropathy and to the fact that the clinical features are similar to the most common optic neuritis. Thus, attention should be drawn during anamnesis, clinical examination and appropriate serological studies in lupus patients, especially in cases of unilateral or bilateral optic neuropathy in any patient, particularly in young women. 